\title{
Home drowning among preschool age Mexican children
}

\author{
Alfredo Celis
}

\begin{abstract}
Objectives-To estimate the risk of drowning by different bodies of water in and near the home for children aged 1 to 4 years.
\end{abstract}

Setting-The Metropolitan Area of Guadalajara, Mexico.

Methods-A population case-control study. Cases $(n=33)$ were children 1 to 4 years old who drowned at their home; controls $(n=200)$ were a random sample of the general population.

Results-The risk of drowning for children whose parents reported having a water well at home was almost seven times that of children in homes without a water well (adjusted odds ratio $(O R)=6.8,95 \%$ confidence interval $(\mathrm{CI})=2.2$ to 20.5). Risk ratio estimates for other bodies of water were: swimming pools $(O R=5.8,95 \%$ $\mathrm{CI}=0.9$ to 37.5$)$, water barrel $(\mathrm{OR}=2.4$, $95 \% \mathrm{CI}=1.0$ to 5.6 ), underground cistern $(\mathrm{OR}=2.1,95 \% \mathrm{CI}=0.8$ to 5.2$)$, and a basin front (courtyard pool to store water) of 35 or more litres $(\mathrm{OR}=1.8,95 \% \mathrm{CI}=0.8$ to 4.4).

Conclusion-Drowning at home is frequent in the Metropolitan Area of Guadalajara, but the causes are different from those reported in developed countries. Accordingly, the preventive strategies must also be different.

(Injury Prevention 1997; 3: 252-256)

Keywords: drowning; home injuries; Mexico; risk factors.

Due to its high incidence in many places around the world, drowning is an important public health issue. It is often most frequent in the 1 to 4 year old group ${ }^{1-6}$ where annual rates are from $5 / 100000$ to $13 / 100000 .^{78}$ As with many other kinds of injury, males are at higher risk. ${ }^{9}{ }^{10}$ In Mexico, from 1985 to 1990,17092 deaths by injury occurred among children aged 1 to 4 years. Of those 3408 events $(19.9 \%)$ were drownings (International Classification of Diseases E910), placing it first in the mortality list. ${ }^{11}$ As well as the high frequency of these events, another important aspect is that $63.1 \%$ happen at home. ${ }^{12}$

The Metropolitan Area of Guadalajara includes approximately three million inhabitants. This population is located 1500 meters above sea level. Although deposits of under- ground water exist, these are insufficient to satisfy the needs of the population. The most important source is the Lake of Chapala, about 50 kilometres away, from which water is pumped. However, cuts are frequent, particu larly in the 'dry' season (approximately fout months every year), during which the rain diminishes and the natural deposits of water diminish. Because of this many people store water in wells, barrels, tubs, pails, and under ground cisterns ('aljibes'; see figure). Due to economic conditions, in this region house with swimming pools or bathtubs are scarce.

Several studies show that almost any body of water at home poses a risk for drowning. Thos $\vec{\varphi}$ most frequently reported are swimming pools, bathtubs, and buckets. ${ }^{813-18}$ However, most of these studies come from developed countrie whose economic conditions are very differen from Mexico. Particularly in the Metropolitat Area of Guadalajara (the second main urbas concentration in Mexico) it has been observe that approximately $60 \%$ of drowning in chil 3 dren aged 1 to 4 years occurred in under? ground cisterns or aljibes. ${ }^{12}$ Other bodies off water associated with drowning in this age group include water wells or draw well $(17.6 \%)$, tubs or buckets $(11.3 \%)$, swimming pools $(4.4 \%)$, and basin fronts (courtyar pools to store water) $(4.4 \%)$ (A Celis, unpubs lished data). None of these has been evaluateक्ष as a risk factor in these localities and some have never been reported in the internationa literature.

Accordingly, the aim of this study was to estimate the relative risk for drowning in the 1 to 4 year age group, presented by different bodies of water found in or near Mexicas. homes.

\section{Methods}

A case-control study was conducted. Casef were children 1 to 4 years of age who were inhabitants of the counties that compose the Metropolitan Area of Guadalajara (Guadalajara, Zapopan, Tonala, and Tlaquepaque) and who were fatally drowned at their hom between 1991 and 1993. All cases werf identified from death certificates provided bo the statistics office of the Jalisco State Public Health Department. Additional informatio was obtained by interview with the mother The date of death was taken as the referencê date, and all other information was related tơे this date.

Controls were children randomly selected from among the urban residents living in the 


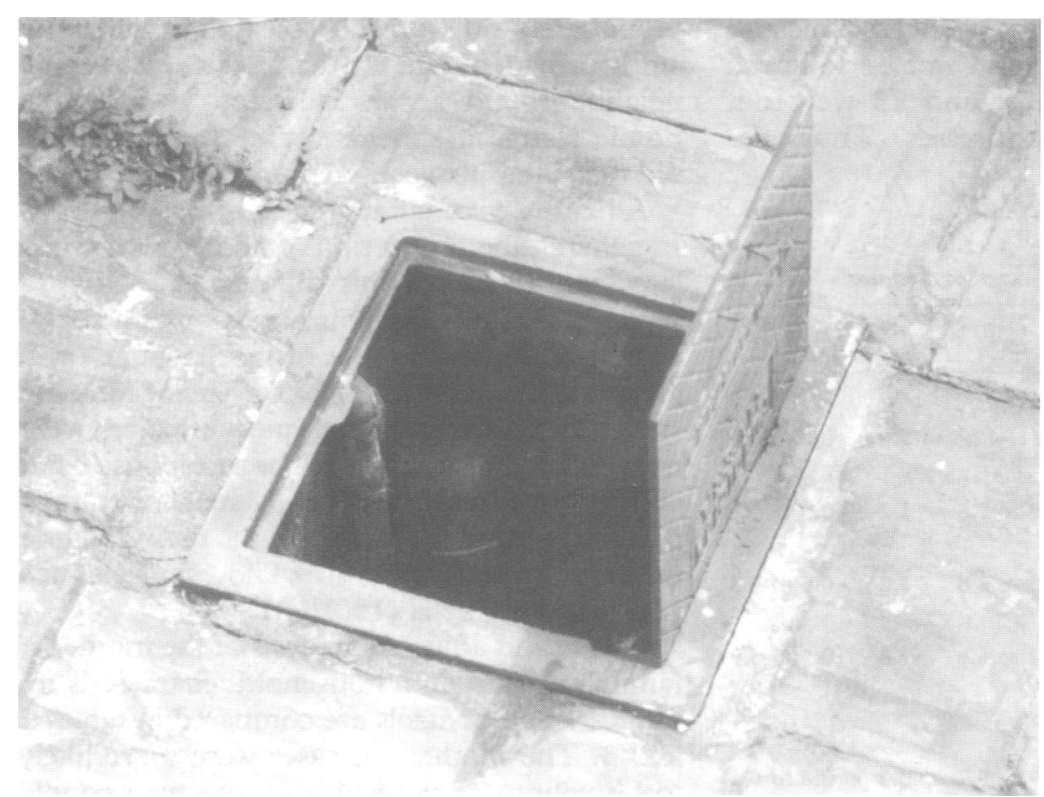

An aljibe or underground cistern.

Metropolitan Area of Guadalajara, matched by sex and age at the time of the reference date of the case (for example, if the case was 2 years old on the date of the drowning, the control had to be between his or her 2 nd and 3rd birthday). For this random selection we used the Metropolitan Area of Guadalajara land register charts by means of the following algorithm in which the house selection was made in two stages: (a) selection of the block and (b) selection of the home. By using the codes contained in the land register, the block was chosen with the aid of randomly selected numbers that pinpoint the land register area, the block, and the sidewalk. From there, all houses in that side of the block were numbered and one was selected randomly.

At each selected home we proceeded as follows: after the presentation and before the initiation of the questionnaire, the interviewer asked if there was another child of the same sex and age living there at the time of death of the case. If not, the next home to the right was chosen, or, in the case of an apartment building, the next greater number was used, until an eligible control was identified.

Interviews were conducted by eight social workers trained in the use of a standardized questionnaire. In all but two interviews the data were obtained directly from the mother of the study child. For the cases, all questions were posed with reference to the date the drowning occurred. For the controls, the questions were made using the reference date, as above.

The variables investigated included characteristics of the child (sex and age); the mother (age, marital status, occupation, education); the head of the household (age, sex, occupation, education); the family (monthly family income, number of members of the family); the household (walls, property, type, construction); and bodies of water (underground cistern, bathtub, buckets and/or tubs, barrels of water, basin front with 35 or more litres, water well, swimming pool). Families of the cases were also asked to describe how the drowning occurred.

Three bodies of water need explanation. Underground cisterns are shaped like a room, with walls, roof, and floor made of concrete. They have a small opening (about $50 \times 50 \mathrm{~cm}$ ) at the top, which is at the same level as the floor of the house. Their capacity varies from 500 to 1000 litres. By barrel we mean a container made of steel, about 200 litres in capacity, into which many liquid substances are delivered to industries (oil, gasoline, etc). In poor areas they are popular. The cover is removed and water is stored in them. Basin fronts (previously explained) are found in every house, but the largest are found in old houses. The water capacity varies, but can reach 200 litres or more. Basin fronts are usually used to wash clothes at home.

Cases were compared with controls to estimate the relative risk of drowning by each body of water. Matched and unmatched analyses were performed and the results compared. Because they were similar, only unmatched results are presented. The odds ratio (OR) and 95\% confidence intervals (95\% CI) were computed for each risk factor using logistic regression ${ }^{19}$ except for two variables that had three categories of outcome. For these, the Mantel-Haenzsel procedure was used and the $95 \%$ CI was calculated by the exact method.

Stratified analyses were used to control for confounding by covariates and to assess interactions. The confounding effects of education (schooling of the head of the household) and brick as the main wall building material (associated with socioeconomic status) were both adjusted. After these were in the model, no further adjustment was necessary; nevertheless, the mother's education was included when examining the effect of the education of the head of the household as a risk factor for drowning. Goodness of fit was assessed graphically by delta-beta values, which are an approximation of the amount that an estimated regression parameter would change if a given observation were omitted from the regression fit. $^{20}$

\section{Results}

From January 1991 to December 1993, 65 home drownings were identified. Data were obtained from 33 cases: of the remainder nine were excluded because the event did not occur

Table 1 Bodies of water at home in which the child fell

\begin{tabular}{lc}
\hline Bodies of water & Frequency (\%) \\
\hline Aljibe (underground cistern) & $13(39.4)$ \\
Bucket/tub & $7(21.2)$ \\
Water well & $5(15.2)$ \\
Barrel & $2(6.1)$ \\
Pot & $2(6.1)$ \\
Bathtub & $1(3.0)$ \\
Puddle & $1(3.0)$ \\
Swimming pool & $1(3.0)$ \\
Basin front & $1(3.0)$ \\
\hline
\end{tabular}


in the home; nine could not be located because the family moved; one could not be followed up after three home visits; and 13 were not located due to wrong addresses. Thus, ap-

Table 2 Characteristics of the mother and head of the family: cases and controls

\begin{tabular}{|c|c|c|c|c|c|c|}
\hline & Cases & Controls & $\begin{array}{c}\text { OR } \\
\text { crude }\end{array}$ & $\begin{array}{l}95 \% \\
C I^{*}\end{array}$ & $\begin{array}{c}\text { OR } \\
\text { adjusted } \dagger\end{array}$ & $\begin{array}{l}95 \% \\
C I^{*}\end{array}$ \\
\hline \multicolumn{7}{|l|}{$\begin{array}{l}\text { Characteristics of the mother } \\
\text { Age (years) }\end{array}$} \\
\hline $\begin{array}{l}<20 \\
\geqslant 20\end{array}$ & $\begin{array}{r}4 \\
27\end{array}$ & $\begin{array}{r}8 \\
192\end{array}$ & $\begin{array}{l}3.6 \\
1.0\end{array}$ & 1.0 to 12.6 & 1.2 & 0.2 to 6.3 \\
\hline \multicolumn{7}{|l|}{ Marital status } \\
\hline $\begin{array}{l}\text { Unmarried } \\
\text { Married }\end{array}$ & $\begin{array}{r}5 \\
26\end{array}$ & $\begin{array}{r}14 \\
184\end{array}$ & $\begin{array}{l}2.5 \\
1.0\end{array}$ & 0.8 to 7.6 & 1.2 & 0.3 to 4.3 \\
\hline \multicolumn{7}{|l|}{ Employment } \\
\hline $\begin{array}{l}\text { Not working } \\
\text { Working }\end{array}$ & $\begin{array}{r}23 \\
8\end{array}$ & $\begin{array}{r}142 \\
58\end{array}$ & $\begin{array}{l}1.2 \\
1.0\end{array}$ & 0.5 to 2.8 & 1.4 & 0.5 to 4.0 \\
\hline \multicolumn{7}{|l|}{ Schooling } \\
\hline $\begin{array}{l}\text { Elementary incomplete } \\
\text { Elementary completed }\end{array}$ & $\begin{array}{l}14 \\
17\end{array}$ & $\begin{array}{r}43 \\
157\end{array}$ & $\begin{array}{l}3.0 \\
1.0\end{array}$ & 1.4 to 6.6 & 1.4 & 0.5 to 3.8 \\
\hline \multicolumn{7}{|c|}{$\begin{array}{l}\text { Characteristics of the head of the family } \\
\text { Age (years) }\end{array}$} \\
\hline $\begin{array}{l}<25 \\
\geqslant 25 \\
\text { Schooling }\end{array}$ & $\begin{array}{r}8 \\
23\end{array}$ & $\begin{array}{r}26 \\
174\end{array}$ & $\begin{array}{l}2.3 \\
1.0\end{array}$ & 0.9 to 5.7 & 2.2 & 0.8 to 6.4 \\
\hline $\begin{array}{l}\text { Elementary incomplete } \\
\text { Elementary completed }\end{array}$ & $\begin{array}{l}16 \\
15\end{array}$ & $\begin{array}{r}33 \\
166\end{array}$ & $\begin{array}{l}5.4 \\
1.0\end{array}$ & 2.4 to 11.9 & $5.1 \ddagger$ & 2.0 to 1.32 \\
\hline
\end{tabular}

Adjusted for schooling of the head of the family and walls of the house.

†Adjusted for schooling of mother and the walls of the house.

Table 3 Characteristics of the family and home cases and controls

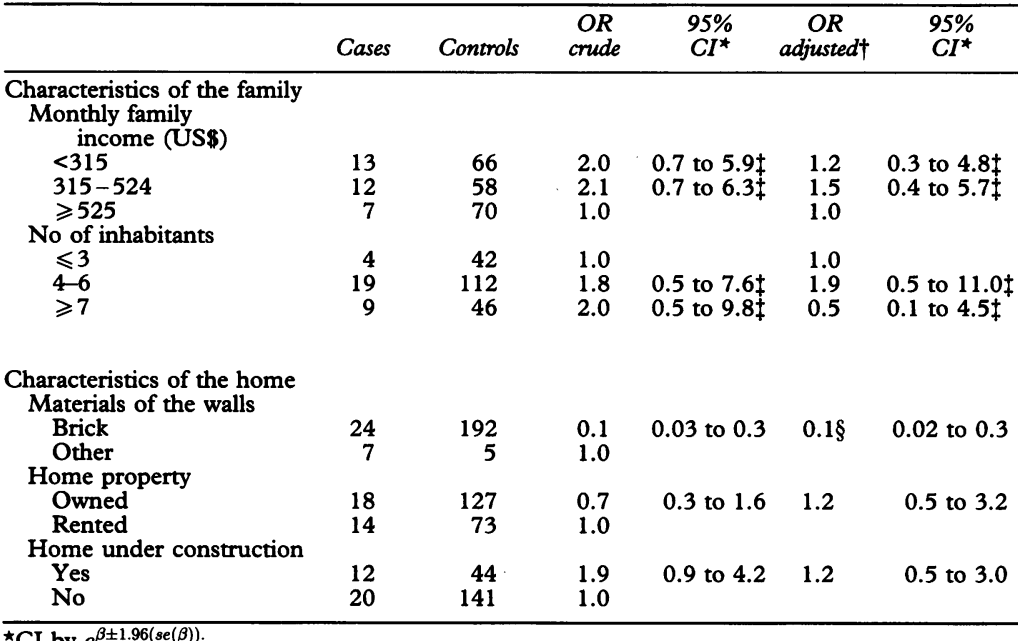

$\star \mathrm{CI}$ by $e^{\beta \pm 1.96(s e(\beta))}$

tAdjusted for schooling of the head of the family and walls of the house.

ICI by exact calculation.

\$Adjusted for schooling of the head of the family.

Table 4 Characteristics of the bodies of water: cases and controls

\begin{tabular}{|c|c|c|c|c|c|c|}
\hline & Cases & Controls & $\begin{array}{c}\text { OR } \\
\text { crude }\end{array}$ & $\begin{array}{l}95 \% \\
C I^{*}\end{array}$ & $\begin{array}{c}\text { OR } \\
\text { adjusted } \dagger\end{array}$ & $\begin{array}{l}95 \% \\
C I^{*}\end{array}$ \\
\hline \multicolumn{7}{|l|}{ Aljibe (underground cistern) } \\
\hline $\begin{array}{l}\text { Yes } \\
\text { No }\end{array}$ & $\begin{array}{l}20 \\
13\end{array}$ & $\begin{array}{r}107 \\
93\end{array}$ & 1.3 & 0.6 to 2.8 & 2.1 & 0.8 to 5.2 \\
\hline \multicolumn{7}{|l|}{ Bathtub } \\
\hline $\begin{array}{l}\text { Yes } \\
\text { No }\end{array}$ & $\begin{array}{r}4 \\
29\end{array}$ & $\begin{array}{r}25 \\
173\end{array}$ & $\begin{array}{l}1.0 \\
1.0\end{array}$ & 0.3 to 2.9 & 0.7 & 0.2 to 2.9 \\
\hline \multicolumn{7}{|l|}{ Bucket/tub 20 or more litres } \\
\hline $\begin{array}{l}\text { Yes } \\
\text { No }\end{array}$ & $\begin{array}{l}22 \\
11\end{array}$ & $\begin{array}{r}148 \\
52\end{array}$ & 0.7 & 0.3 to 1.5 & 0.6 & 0.2 to 1.5 \\
\hline \multicolumn{7}{|l|}{ Barrel of water } \\
\hline $\begin{array}{l}\text { Yes } \\
\text { No }\end{array}$ & $\begin{array}{l}16 \\
17\end{array}$ & $\begin{array}{r}53 \\
147\end{array}$ & $\begin{array}{l}2.6 \\
1.0\end{array}$ & 1.2 to 5.5 & 2.4 & 1.0 to 5.6 \\
\hline \multicolumn{7}{|l|}{ Basin front 35 or more litres } \\
\hline $\begin{array}{l}\text { Yes } \\
\text { No }\end{array}$ & $\begin{array}{l}16 \\
17\end{array}$ & $\begin{array}{r}60 \\
140\end{array}$ & $\begin{array}{l}2.2 \\
1.0\end{array}$ & 1.0 to 4.6 & 1.8 & 0.8 to 4.4 \\
\hline \multicolumn{7}{|l|}{ Water well } \\
\hline $\begin{array}{l}\text { Yes } \\
\text { No }\end{array}$ & $\begin{array}{r}9 \\
24\end{array}$ & $\begin{array}{r}12 \\
188\end{array}$ & $\begin{array}{l}5.9 \\
1.0\end{array}$ & 2.2 to 15.4 & 6.8 & 2.2 to 20.5 \\
\hline \multicolumn{7}{|l|}{ Swimming pool } \\
\hline $\begin{array}{l}\text { Yes } \\
\text { No }\end{array}$ & 31 & $\begin{array}{r}4 \\
195\end{array}$ & $\begin{array}{l}3.1 \\
1.0\end{array}$ & 0.6 to 17.9 & 5.8 & 0.9 to 37.5 \\
\hline
\end{tabular}

†Adjusted for schooling of the head of the family and walls of the house. proximately $60 \%$ of the cases eligible for the study provided data for the analysis. Using the neighbourhood as an indicator of socioeconomic status, it appears socioeconomic status. did not differ between missing and study casesp

All cases were compared with 200 controls. In general, the proportion of non-response was less than $10 \%$, but this differed according to social group: in neighbourhoods of high socio economic status the rate of non-response was greater than in those of lower socioeconomig status. Unfortunately, the questionnaires wer not designed to register this non-response data.

The places where drownings most often tooR place are shown in table 1: they include underground cisterns (39.4\%), buckets/tubß $(21.2 \%)$, and wells $(15.2 \%)$.

Crude and adjusted analysis of the mother's family's head, and household characteristiois for cases and controls are compared in tables $\mathbb{2}$ and 3. The mothers of cases were more likeli to be young (adolescents), to live as a couple with someone but unmarried, without paic employment, and were less well educated Similarly, the family heads of the cases were more likely to be young and with only primarf school education. Case families reported lowe $\vec{b}$ family income, more family members, an\& more often lived in houses under construction than controls.

The crude and adjusted risk factors for drowning by different bodies of water are presented in table 4 . The presence of wello was the strongest risk factor, with almost si times the risk (OR 5.9; 95\% CI 2.2 to 15.4) of those who did not have a well. The second strongest association was with swimming poots (OR 5.8; 95\% CI 0.9 to 37.5). Weake associations were found with barrels of water (OR 2.4; 95\% CI 1.0 to 5.6) and undergroung cisterns (OR 2.1; 95\% CI 0.8 to 5.2 ), while bathtubs, buckets/tubs, and basin fronts di $\$$ not show any significant association.

From table 4 we can also estimate the prevalence of different bodies of water foun in Guadalajara. As we see from the controls $53.5 \%$ of households have underground cis terns, $12.6 \%$ have a bathtub, $74.0 \%$ a buckets tub of 20 or more litres, $20 \%$ a barrel of water? $30 \%$ a basin front of 35 or more litres, $6.0 \%$ well, and $2.0 \%$ a swimming pool. The pre valence of all bodies of water except bathtubs and buckets/tubs were higher in case houses holds: underground cisterns in $60.6 \%$, bathtu仙 in $12.1 \%$, buckets/tubs in $66.7 \%$, barrel of water in $48.5 \%$, water well in $27.3 \%$, and swimming pool in $6.1 \%$.

\section{Discussion}

This study identifies different bodies of waters some not reported previously, in which chile dren 1 to 4 years old drown at home. 遇 provides estimates of the association between drowning and the presence of these deposits? Several characteristics of the home revealed in this study need to be considered when for? mulating preventive measures to diminish the frequency of this public health problem.

The study shows that almost any water 
deposit represents a risk factor for drowning among preschool age children. Due to their frequency or strong association, several demand special attention, such as wells and residential swimming pools. However, because these are scarce in Guadalajara this explains why only six children drowned in them. A less strong association was found with barrels, large basin fronts, and underground cisterns. The latter are popular in Guadalajara and are where most children drown. Because of their high prevalence among controls, however, the association is not as strong as that for wells. Nevertheless, the number of casualties are large enough to warrant a study to identify which part of the cisterns is related to these drownings.

These data do not allow us to measure the drowning risk that buckets and tubs represent. Jumberlic and Chambliss suggested that buckets with a capacity of 20 or more litres represent a major risk, ${ }^{16}$ while our results suggest that buckets of this size could represent the same risk as those with a smaller capacity. Without affecting their functional usefulness, such buckets could be designed with an unstable base so that when a child falls into one, the bucket tips easily, allowing the water to spill.

Our results also show that asphyxia by immersion in the home is strongly associated with the socioeconomic conditions of the family. Although family income does not show an important association, the educational level of the head of the household and the characteristics of the home (that also indicate social status) stand out as risk factors. In Guadalajara, families of very low socioeconomic status use material other than brick (or other stonelike materials) for home construction. It is of particular importance to highlight that this characteristic is a proxy that may allow us to identify groups with an increased risk of drowning.

Several limitations require consideration. Not being able to locate some cases influences the results. We believe, however, that this results in a bias toward the null. A previous study in the same city found that $56.1 \%$ of drownings at home happened in underground cisterns, ${ }^{12}$ while in this study only $39.4 \%$ of cases reported being drowned in an aljibe. It seems that families of cases that drowned in underground cisterns change their address more frequently than controls. This would bias our results toward the null hypothesis, because the frequency in which an aljibe is reported for a case would approach that of controls. We do not have previous reports for other bodies of water, but it is reasonable to assume that if families move because they do not wish to live in a place where their child drowned, all other risk estimates will also tend to the null.

A second limitation is that the data collected were based on the informant's memory. It could be that mothers of cases remember more about water systems at home than mothers of controls. However, almost all bodies of water can be observed, and their presence and characteristics remain for a long time. On the other hand, the absence of previous home drowning studies prompt us to assume that recall bias would be small.

Controlling for confounding could be incomplete. Before this study there were no reports to guide the associations being examined. Possible confounding factors such as age, sex, and indicators of social status have been reported in relation to other injury deaths. Cases and controls were matched by age and sex, and the results show that these did not have a confounding affect. Correlates of social condition were used to control for their obvious effects in the statistical analysis.

Finally, although it was impossible to prevent the interviewers from knowing the case or control status or the subjects interviewed, and this could introduce an information bias, to diminish this we used a standardized questionnaire and trained interviewers.

The study also has several advantages that merit attention. The control group was randomly selected from the community, thus enabling us to estimate the prevalence of bodies of water at home and relative risks for drowning that have not been reported previously. Moreover, the cases and controls were population based and this diminishes the probability of selection bias. As the case and control interviews were identical, the risk of differential misclassification is lessened.

\section{Implications for prevention}

This investigation shows that the problem of drowning at home by 1 to 4 year old children in the Metropolitan Area of Guadalajara, although occurring with the same frequency as reported by other investigators, involves different aetiological characteristics than those reported previously in developed countries. Accordingly, the preventive strategies for Guadalajara must also be different. The characteristics of bodies of water not reported previously, and their relation with drowning, should be studied in depth.

1 Fingerhut LA, Kleinman JC, Malloy MH, Feldman J Injury fatalities among young children. Public Health Rep 1988; 103: $399-405$.

2 Barell V, Zadka P, Halperin B, Sidransky E. Childhood mortality from accidents in Israel, 1980-84. Isr F Med Sci 1990; 26: $150-7$.

3 Keeling JW, Golding J, Millier HKGR. Non-natural deaths in two health districts. Arch Dis Child 1985; 60: 525-9.

4 Knobel GJ, de Villiers JC, Parry CD, Bith JL. The causes of non-natural deaths in children over a 15-year period in greater Cape Town. $S$ Afr Med f 1984; 66: 795-801.

5 De Mello MH. Mortes violentan em menores de 15 años no Brasil. Bol Oficina Sanit Panam 1986; 100: 590-603.

6 Información Estadística Sector Salud y Seguridad Social. Mexico: Instituto Nacional de Geografia Estadística e Informatica, 1989.

7 Division of Injury Control, CDC. Childhood injuries in the United States. Am $\mathcal{F}$ Dis Child 1990; 144: 627-46.

8 Pearn JH, Wong RYK, Brown III J, Ching Y, Bart $R$ Hammar S. Drowning and near-drowning involving children: a five-year total population study from the city and county of Honolulu. Am $\mathcal{F}$ Public Health 1979; 69: $450-4$.

9 Dietz PE, Baker SP. Drowning. Epidemiology and prevention. Am f Public Health 1974; 64: 303-12.

10 Mizuta R, Fujita H, Osamura T, Kidowaki T, Kiyosawa N. Childhood drownings and near-drownings in Japan. Acta Paediatr Fpn 1993; 35: 186-92.

11 Bases de datos de certificados de defunción. Mexico 1985-1990. INEGI-Secretaria de Salud. 
12 Celis A. Asfixia por inmersion en Jalisco, 1983-1989. Salud Publica Mex 1991; 33: 585-9.

13 Budnick LD, Ross DA. Bathtub-related drowning in the United States, 1979-81. Am f Public Health 1985; 75: $630-3$.

14 O'Carroll PW, Alkon E, Weiss B. Drowning mortality in Los Angeles County, 1976 to 1984. $\mathscr{F} M A$ 1988; 260: 380-3.

15 Pearn J, Nixon J, Wilkey I. Freshwater drowning and neardrowning accidents involving children. A five-year total population study. Med $\mathcal{F}$ Aust 1976; ii: $942-6$.
16 Jumberlic MI, Chambliss $M$. Accidental toddler drowning in 5-gallon buckets. $\mathcal{F} A M A$ 1990; 263: 1952-3.

17 Gardiner SD, Smeeton WM, Koelmeyer TD, Cairns FI Accidental drowning in Auckland children. NZ Me $\bar{\hbar} \mathcal{F}$ 1985; 98: $579-82$

18 Mann MC, Weller SC, Rauchshwalbe R. Bucket-related drownings in the United States, 1984 through 19\$्शे.

19 Hosmer DW, Lemeshow S. Applied logistic regression. N York: Hohn Willey and Sons, 1989.
20 EGRET. Reference manual. Seattle, WA: SERC, 1992.

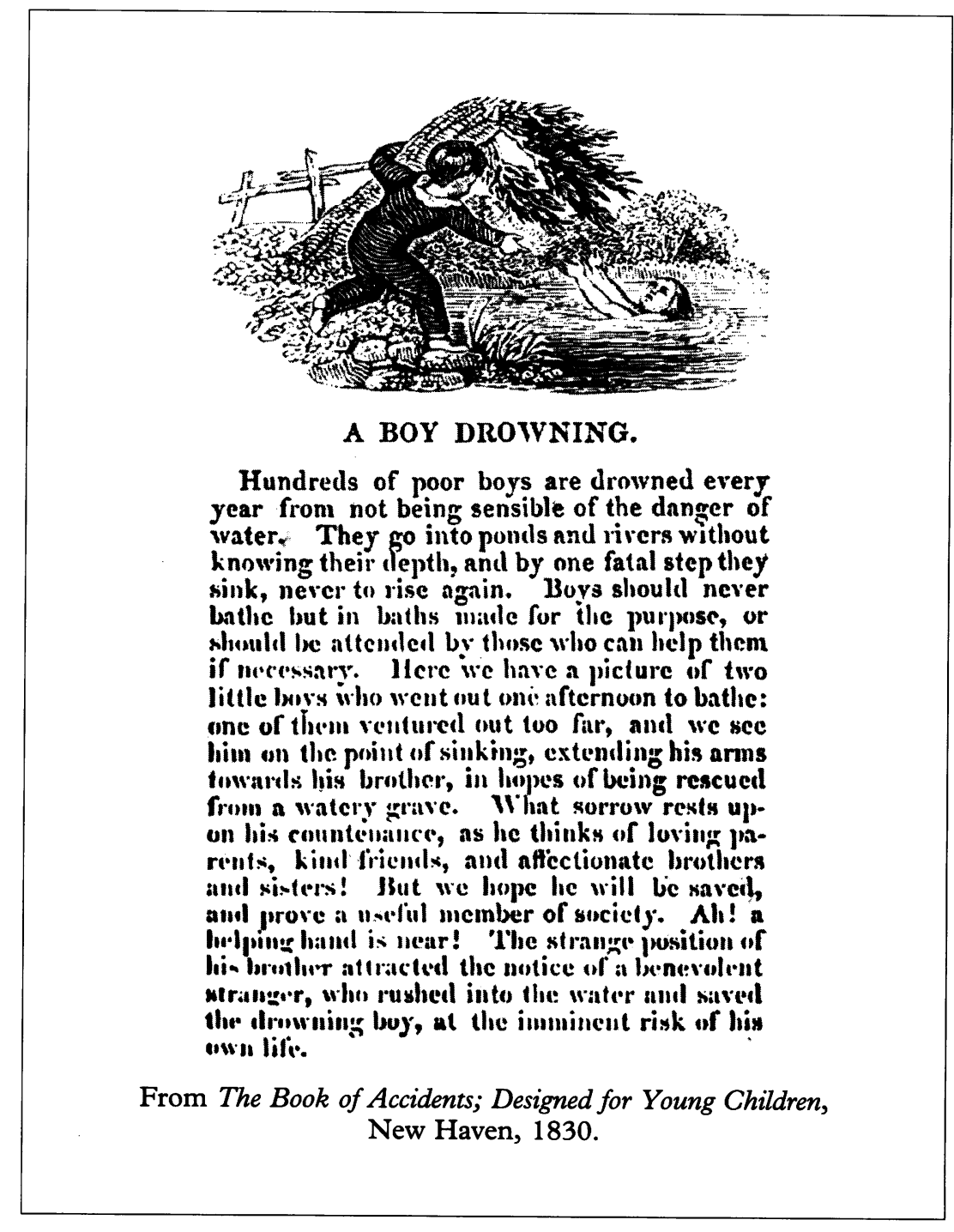

